\title{
Phonological Characteristics of 4- to 5-Year-Old Children in Nonword Repetition under Different Phonetic Complexity
}

\author{
A Rum Kim ${ }^{a}$, Ran Lee ${ }^{a}$, Jin Soon Han ${ }^{a}$, Eun-Ju Lee ${ }^{b}$ \\ ${ }^{a}$ Department of Speech and Language Pathology, Graduate School, Dankook University, Yongin, Korea \\ ${ }^{b}$ Department of Special Education, Dankook University, Yongin, Korea
}

Correspondence: Jin Soon Han, $\mathrm{PhD}$ Department of Speech and Language Pathology, Dankook University, 152 Jukjeon-ro, Suji-gu, Yongin 16890, Korea

Tel: $+82-31-8005-2278$

Fax: +82-31-8021-7144

E-mail: jinsoonhan@hotmail.com

Received: July 5, 2017

Revised: August 22, 2017

Accepted: August 28, 2017

This paper is based on the master's thesis of the first author.

\begin{abstract}
Objectives: This study investigated whole-word phonological characteristics and articulation error types through nonword repetition under different phonetic complexity to examine the effect of phonetic complexity on phonological characteristics and articulation error frequencies. Methods: Forty-five typically developing children aged 4-5 participated as subjects and were divided into three group: early 4 years old, late 4 years old, and early 5 years old. A repetition task using 50 nonwords was performed with the respective groups to investigate inter- and intra-group differences in whole-word analysis indexes and frequencies of articulation error by type according to phonetic complexity scores (low/high). Results: Significant differences were found in the whole-word analysis indexes between age groups and phonetic complexity. The interaction effects of phonetic complexity and age group were also significant. Significant differences were found between the early 4 years old and late 4 years old, and between early 4 years old and early 5 years old. Differences between late 4 years old and early 5 years old were significant in word correctness, whereas a difference among age groups was not found in word variability of nonwords with low phonetic complexity. Frequency of articulation error by type was higher for nonwords with high phonetic complexity. Articulation error by type occurred most frequently among the early 4 years old. As for articulation error by type, substitution occurred most frequently, followed by omission and addition. Conclusion: Results supported the previous studies suggesting that articulation error frequency is higher for nonwords with high phonetic complexity, and thus indicated the necessity for word selection allowing for phonetic complexity when conducting clinical phonological assessment and intervention.
\end{abstract}

Keywords: Phonetic complexity, Whole-word phonological analysis, Nonword repetition test
학령전 아동의 초기 음운 평가에는 음소를 단위로 분석하는 방 법과 단어를 단위로 분석하는 방법이 있다. 자음정확도(percentage of correct consonants, PCC)는 음소(자음)를 단위로 하여 아동이 산출한 자음 중 바르게 산출한 자음의 비율을 말하는(Kim, 2005) 개별 음소에 대한 측정치로서 단어 내 특정 위치에 오는 목표 자음 의 정조음 여부만을 살펴본다. 따라서 아동이 성인 어휘에 근접한 산출이 가능한지 여부(Suk, 2004)와 단어단위에서 일관되게 틀리 는 아동의 음운 특성을 살펴보는 데에는 제한적일 수 있다(Shin \&
Lee, 2015). Ingram과 Ingram (2001)은 자음정확도에 대한 대안으 로 개별 음소가 아닌 단어를 단위로 하여 아동의 음운능력을 평가 하는 단어단위 분석(whole word analysis)을 제안하였다. 자음정확 도와 높은 상관을 보이는 평균음운길이(proportion mean length of utterance, PMLU)를 포함하는(Ha \& Hwang, 2013) 단어단위 분 석 지표를 이용하면 자음정확도로는 파악할 수 없었던 단어단위 전체의 정확성과 음소가 산출되는 단어의 길이와 음운적 복잡성, 변이성 등의 다양한 음운 특성을 살펴볼 수 있으며(Ha \& Hwang, 
2013; Suk, 2006), 조음발달 과정에서 나타나는 개인차와 가변성을 객관적으로 평가할 수 있다(Park \& Suk, 2012).

단어단위 분석 지표를 이용한 선행연구들은 연령 증가에 따른 음운 능력과 발달에 대한 정보 및 패턴을 이해하고자 하였다. 만 2-4세 일반아동을 대상으로 단어단위 분석을 실시한 Park과 Suk (2012)의 연구에서는 아동의 연령이 높아짐에 따라 단어 정확률 (proportion of whole word correctness, PWC), 단어 평균음운길 이, 단어 근접률(proportion of whole word proximity, PWP)은 증 가하고, 단어 변이율(proportion of whole word variability, PWV) 은 감소하였다. 단어와 문장 수준에서 만 2 세 6 개월-4세 아동의 조 음오류율, 조음변이성, 조음오류변이성을 살펴본 Hwang과 $\mathrm{Ha}$ (2012) 의 연구에서는 만 2 세 6 개월부터 3 세 11 개월 사이에 조음변이성과 조음오류변이성이 감소하다가 만 4세에는 안정적인 조음 수행을 보 인 것으로 나타났다. 또한, 만 3-5세 일반아동을 대상으로 이루어 진 Suk (2006)의 연구에서는 연령이 높아짐에 따라 단어 정확률, 복잡률, 근접률이 증가하면서, 연령 집단 간의 차이가 유의하였다. 만 5-7세 일반아동을 대상으로 이루어진 Park과 Son (2012)의 연구 에서도 단어 정확률, 평균음운길이, 근접률에서 동일한 결과가 나 타났으나, 단어 변이율에서의 연령 집단 간 차이는 유의하지 않았 다. 이러한 선행연구 결과를 종합하면, 아동의 연령이 증가함에 따 라 단어 변이율이 감소하고 일관된 단어 산출 형태를 보이면서 조 음 수행이 안정된다.

단어단위 분석 지표는 근본적으로 자발화를 대상으로 음절, 단 어, 어절을 단위로 하여 각 언어학적 단위에서 나타난 말소리 특성 을 분석하기 위해 개발된 것이다(Kim \& Shin, 2015). 말소리 및 음 운발달 평가에 단어단위 분석 지표를 이용한 선행연구들은 한국 표준 그림 조음음운 검사(Korea Standard Picture Articulatilon and Phonological Test, KS-PAPT; Park \& Suk, 2012)의 검사 단어, 놀이상황에서 아동이 산출한 대화 샘플(Suk, 2006), 임의로 선정 한 2-4음절 의미단어(Hwang \& Ha, 2012)를 이용하여 단어단위 분 석 지표를 산출하였다. 그러나 분석단위가 되는 단어가 친숙하지 않거나 새로 습득한 것일 때 변이성이 높다고 보고한 Kim과 $\mathrm{Ha}$ (2016)의 연구 결과에서 알 수 있듯이, 의미단어는 개별아동의 어휘 친숙도와 의미적 난이도에 따라 조음 산출에 서로 다른 영향을 미 친다. 따라서, 언어적 배경지식의 영향은 배제하면서도 음운처리 (phonological processing)를 파악할수 있다는 장점이 있는 비단어 따라말하기 과제(Chon \& Ambrose, 2016)를 이용하여 단어단위 분석 지표를 산출하고 아동의 음운 특성을 살펴볼 필요가 있다. 비 단어 따라말하기(nonword repetition)는 검사자가 들려주는 비단 어를 듣고 아동이 즉시 따라 말하는 과제로, 정확한 수행을 위해서
는 음향신호 지각, 언어처리, 말 산출능력의 협응이 필요하며(Hwang, 2015), 음운기억과 같은 언어 영역과 말 산출과정의 선별에 활용할 수도 있다(Hwang, 2015; Hwang \& Ha, 2010; Lee \& Sim, 2003; Oh \& Yim, 2013). 따라서 어휘 친숙도와 의미적 난이도 등의 효과를 통 제하면서도 단어가 갖는 음운적 복잡성이 단어의 음성적 실현에 미치는 영향을 알아보기 위하여 음소와 음소의 연쇄가 충분히 우 리말의 단어처럼 들리는 비단어 따라말하기 과제를 제작하기 위해 서는 간섭효과는 통제하면서도 우리말의 음소 출현빈도, 음절구 조, 음절길이 등을 고려하여 우리말의 의미단어와 유사한 형태를 띠도록 해야 한다.

아동은 음절 수가 많은 단어나 상대적으로 늦게 발달되는 말소 리가 초성이나 종성에 포함된 어절에서 더욱 변이적인 조음 특성을 보이는 등( $\mathrm{Kim} \& \mathrm{Ha}, 2016)$ 음운구조가 복잡해지면 단어 내 분절 음의 산출을 어렵게 만들어 조음 산출에 영향을 미친다(Kim, Choi, \& Park, 2006). 따라서 우리말의 조음발달 및 특성을 적용한 조음 복잡성지표(index of phonetic complexity, IPC)를 고려하여 조음 복잡성이 단어의 조음에 미치는 영향을 파악해야 할 뿐만 아니라, 말산출과 관련된 평가와 치료에서도 오류가 발생한 개별 음소뿐만 아니라 오류가 포함된 환경을 함께 고려해야 할 필요가 있다(Lee, Han, \& Sim, 2004). 조음복잡성지표는 Jakielski (1998)가 단어 단위 에서 개별 말소리의 음운 및 음성학적 특성에 따라 체계적으로 가 중치를 부여하여, 해당 단어의 조음복잡성(phonetic complexity) 정도를 판정하기 위해 고안한 지표이다(Dworzynski \& Howell, 2004; Lee et al., 2004; as cited in Shin \& Ha, 2015). 목표 어절의 조 음복잡성 정도를 산출하기 위해 Lee 등(2004)은 Dworzynski와 Howell (2004)의 지표 체계를 토대로 각 어절에서 나타난 개별 음소 의 음성학적 특성, 음절구조, 어절 내 인접자음의 동시조음의 용이 성 여부 등을 통합하여 한국어 조음복잡성지표 체계를 고안하였 다. 한국어 조음복잡성지표 체계를 토대로 조음복잡성을 고려한 비단어를 제작하여 4-6세 9개월 말더듬아동과 일반아동의 따라말 하기 수행력을 살펴본 An (2012)의 연구에서는 조음복잡성 점수 (저/고)에 따른 비단어 따라말하기 정반응율이 조음복잡성 저단어 와 고단어 모두 일반아동보다 말더듬아동이 유의하게 낮았으며, 조음복잡성이 높은 과제의 정반응률은 낮은 과제보다 유의하게 낮 았다. Hwang (2015)은 비단어의 길이와 조음복잡성이 5-9세 일반 아동의 비단어 따라말하기 수행능력에 어떤 영향을 미치는지 알아 보기 위하여 조음복잡성을 고려한 2-5음절 비단어 따라말하기 과 제를 제작하여 연구를 진행하였다. 그 결과 연령이 증가함에 따라 비단어 따라말하기 수행이 향상되었고, 조음복잡성이 높은 비단어 보다 낮은 비단어에서의 수행이 더 좋은 것으로 나타났다. 아동의 
음운 특성을 자세히 살펴보기 위해서는 전반적인 조음복잡성지표 를 고려한 비단어 제작이 필요하나 An (2012)과 Hwang (2015)은 비단어 제작 시 조음복잡성지표 중 2-3개만을 반영하거나 발달적 으로 나중에 습득되는 자음은 포함시키지 않는 등 한국어의 음운 특성 및 음절구조를 제한적으로 고려하였다. 따라서 전반적인 조 음복잡성지표를 고려한 비단어를 제작하여 조음복잡성에 따른 비 단어 따라말하기 수행 능력뿐만 아니라 음운 특성에 대한 정보를 파악할 필요가 있다. 이를 통해 조음복잡성이 높은 단어와 낮은 단 어에서 나타나는 아동의 음운 특성에 대한 정보를 얻을 수 있으며, 이는 말소리 평가와 중재에 중요하게 활용될 수 있을 것이다.

조음복잡성지표를 이용한 선행연구들 중 일부(Lee et al., 2004; Shin \& Ha, 2015)는 조음복잡성과 음운 능력의 상관관계를 알아보 기 위해 조음오류를 살펴보았다. 조음오류를 목표 말소리와 비교하 여 분석하는 방법을 이용하여 음절구조가 변하는 생략과 첨가, 음 소가 변하는 대치와 왜곡으로 유형을 나누어서 아동의 음운 특성 을 살펴보았다(Kim \& Shin, 2007). 말더듬아동과 성인을 대상으로 조음복잡성이 비유창성과 조음오류에 미치는 영향을 살펴본 Lee 등(2004)은 조음복잡성이 높을수록 조음오류의 빈도가 유의하게 증가함을 보고하였다. 학령전 말소리장애 아동을 대상으로 조음 복잡성에 따른 비유창성과 조음오류 특성을 연구한 Shin과 $\mathrm{Ha}$ (2015)는 조음복잡성이 낮은 단어보다 높은 단어에서 조음오류 출 현율이 유의하게 높았으나 조음복잡성이 낮은 단어와 높은 단어에 서 나타난 오류 유형의 비율에서는 유의한 차이가 없었음을 보고 하였다. 즉, 조음복잡성이 낮은 단어와 높은 단어에서 조음오류가 달리 나타나며, 조음복잡성은 일반 아동의 음운 실현에도 영향을 미칠 수 있으므로 음절길이와 구조 및 음소연쇄의 출현빈도 측면에 서 우리말 의미단어와 매우 유사하나 의미적 난이도를 통제한 비 단어 따라말하기 과제에서 조음복잡성이 일반아동의 단어단위 음 운 특성에 미치는 영향을 살펴볼 필요가 있다. 따라서 본 연구는 조 음복잡성 점수가 낮은 비단어와 높은 비단어 목록을 제작한 후 따 라말하기 과제를 실시하여, 조음복잡성(저/고)에 따른 비단어 따라 말하기에서 나타나는 만 4 세 전반, 4 세 후반, 5 세 전반 아동의 단어 단위 음운 특성과 조음오류 유형별 빈도를 알아보고자 하였다.

\section{연구방법}

\section{연구대상}

본 연구는 서울.경기 지역에 거주하는 4세 전반(4;0-4;5, 남 4, 여 11), 4세 후반(4;6-4;11, 남 6, 여 9), 5 세 전반(5;0-5;5, 남 8, 여 7) 아동 15 명씩, 총 45 명을 대상으로 실시하였다. 습득 전의 음소는 모두 일
관된 오류를 보이다가 음소가 확립되면서 음운 환경에 따라 정확하 게 산출하거나 오류를 보이며 정확한 산출로 가는 전이 단계에는 변이적인 형태로 말소리를 산출한다(Kim \& Ha, 2016). 따라서 본 연구에서는 산출하기 어려운 어중종성의 위치에서도 우리말의 7 종성이 완전히 습득되어 전달구 수준의 따라말하기 조건에서도 친 숙도가 낮고 사용빈도가 매우 낮은 고유낱말을 정조음할 수 있는 (Kim, 2012) 조음 발달의 안정화 시기인 만 4세 전반, 4 세 후반, 5 세 전반을 대상으로 선정하였다(Kim \& Pae, 2005). 또한 같은 연령대 내에서도 월령의 차이에 따라 다르게 나타나는 말소리 발달 특성 을 파악하고자 6개월 단위로 연령을 구분하였다(Park \& Suk, 2012). 연구대상의 선정기준은 (1) 수용·표현어휘력검사(Receptive \& Expressive Vocabulary Test, REVT; Kim, Hong, Kim, Jang, \& Lee, 2009)의 수용어휘력검사 결과가 -1 SD 이상에 해당하며, (2) 아동 용 발음검사(Assessment of Phonology and Articulation for Children, APAC; Kim, Pae, \& Park, 2007)의 단어검사에서 산출된 개 정 자음정확도의 백분위 점수가 $20 \% \mathrm{ile}$ 이상이고, (3) 아동의 부모 또는 담당 교사에 의해 지적능력 저하, 언어발달 지연, 기타 동반장 애가 없는 것으로 보고된 아동이다. 이 선정기준에 부합하여 연구 에 참여한 대상자의 말.언어검사 결과는 Table 1 과 같다.

\section{연구도구}

Lee 등(2004)의 연구에서 사용한 한국어 IPC 및 배점 기준 Table 2 를 참고하여 비단어를 제작하였다.

연구결과를 의미단어를 기본으로 하는 단어단위 분석에 적용하 기 위하여 다음의 기준을 적용하여 비단어의 음운구조를 우리말 에서 출현할 가능성이 높고 의미단어와 유사한 구조로 제작하였 다. 1 음절 비단어는 지표 6 인 인접자음의 출현여부와 지표 7 인 인접 자음의 조음위치를 반영하지 못하기 때문에 제외하였다. 또한 우리 말의 음절길이는 2음절어가 가장 많고, 3 음절어가 이를 뒤이으며, 기초어휘의 경우 2음절어가 전체의 절반을 차지한다(Bae, 2014). 따 라서 4 음절 이상의 비단어는 제외하고, 한국어에 가장 많은 2,3 음 절까지만 검사어에 포함하였다. 2,3 음절 비단어 중 조음복잡성이

Table 1. Group characteristics

\begin{tabular}{lccc}
\hline & \multicolumn{3}{c}{ Age group } \\
\cline { 2 - 4 } & $4 ; 0-4 ; 5(\mathrm{~N}=15)$ & $4 ; 6-4 ; 11(\mathrm{~N}=15)$ & $5 ; 0-5 ; 5(\mathrm{~N}=15)$ \\
\hline REVT & $44.0(4.40)$ & $56.0(4.59)$ & $65.2(5.83)$ \\
APAC (\%) & $94.8(2.45)$ & $97.7(1.66)$ & $98.2(1.20)$ \\
\hline
\end{tabular}

Values are presented as mean (SD).

REVT = Receptive \& Expressive Vocabulary Test (Kim, Hong, Kim, Jang, \& Lee, 2009); $\mathrm{APAC}=$ Assessment of Phonology and Articulation for Children (Kim, Pae, \& Park, 2007). 
Table 2. Korean IPC scoring schema

\begin{tabular}{lll}
\hline Individual index & \multicolumn{1}{c}{ No point } & One point each \\
\hline Index 1. Place of consonants & Bilabials, alveolars, glottals & Alveopalatals, velars \\
Index 2. Manner of consonants & Stops, nasals & Fricatives, affricates, liquids \\
Index 3. Type of vowel & Monophthong & Diphthong \\
Index 4. Syllable structure & Ends with a vowel (opened) & Ends with a consonant (closed) \\
Index 5. Length of words & $1-2$ syllable(s) & 3 syllables more \\
Index 6. Presence of consonant cluster & Absent & Present \\
Index 7. Homorganicity of consonant cluster & Homorganic & Heterorganic \\
\hline
\end{tabular}

$\mathrm{IPC}=$ index of phonetic complexity.

낮은 단어(이하, 조음복잡성 저단어)는 1 개 또는 2 개, 조음복잡성 이 높은 단어(이하, 조음복잡성 고단어)는 6개 또는 7개의 조음복 잡성지표를 반영하여 만들 수 있는 모든 항목을 고려하였다. 2 음절 의 조음복잡성 저단어 14 문항은 조음복잡성 점수가 1-2점, 조음복 잡성 고단어 13 문항은 7-9점이었고, 3 음절 조음복잡성 저단어 14 문항은 2-3점, 조음복잡성 고단어 12문항은 12-15점으로 총 53개 의 문항을 선정하였으며, 각 문항마다 3 개의 비단어를 제작하여 총 159 개의 예비문항을 선정하였다.

이론적으로 가능한 2-3음절 비단어 중 최종 검사어를 선정할 때 고려한 사항은 다음과 같다. 자음의 조음위치(지표 1) 및 조음방법 (지표 2)과 관련하여 비단어 내에 동일한 조음 위치 및 방법의 음소 가 2개 이상 들어가지 않았다. 어두초성 /리 (예: 라붐)은 / ㄴ/으로 대치하여 실현하기 쉽고, 어중초성 /ㅎ/ (예: 고형)은 생략하기 쉬우 므로 제외하였다(Kim, 2005). 구어에서 출현할 가능성이 낮은 두 음소가 연쇄되는 비단어는 한국어로 인식되지 않기 때문에 두 음 소의 전이빈도가 $0.1 \%$ 이하인 음소연쇄는 제외하였다(Hwang, 2015). 모음의 종류(지표 3)와 관련하여 자음이 이중모음과 결합된 음절은 3-8세 아동의 자발화 연구(Shin, 2005)에서 가장 높은 빈도 로 출현하는 것으로 보고된 / / / / / / / / / 교/와 성인의 자발화 연구 (Shin, 2008)에서 $0.2 \%$ 이상의 출현빈도를 보이는 것으로 보고된 음 절 /냐/, /녀/, /려/, /겨/, /며/, /벼/, /혀/, /교/ 중에서 위에서 제외 요인으 로 기술한 것처럼 자음 / ᄂ/, /리이 포함된 이중모음 음절을 제외한 뒤 /겨/(0.4\%), /며/(1.2\%), /벼/(0.2\%), /혀/(0.2\%), /교/(0.2\%)로 선정 하였다. 이 중 조음복잡성 점수가 2점인//겨///혀/, /교/의 우선 순위 는 조음복잡성 점수가 1점인 /며/가 /벼/에 비해 출현 빈도가 더 높 다는 한국어 음소 전이빈도 연구(Shin, 2008)를 참고하여 /겨/, /혀/, /교/로 선정하였다. 음절의 형태(지표 4)와 관련하여 7 개 종성 중 /ㄷ/, / ᄀ / 은 불파음으로 실현되므로 청지각적으로 실현 여부를 구 분하기 어렵기 때문에 제외하였다(Hwang, 2015). 이중모음 뒤에 오 는 종성 중 출현빈도가 $0.2 \%$ 미만인 /ㅁ, 비은 제외하였다(Shin,
2008). 그 다음으로 어절의 길이(지표 5)와 관련하여 조음복잡성 저단어와 고단어 목록에 각각 2 음절과 3 음절을 포함시켰다. 인접 자음의 출현여부(지표 6)와 인접자음의 조음위치(지표 7)와 관련 하여 어중 자음연쇄의 음운배열규칙에 따라 배제된 연쇄와 어말종 성 및 어두초성의 두 음소 빈도(Kim, 2010; Shin, 2008)를 고려하여 $0.1 \%$ 이하인 비단어는 제외하였다. 어중 자음연쇄 중 어중 종성 /르, ㄴ/과 어중초성 / ᄌ, ㅉ, 치의 연쇄는 두 자음 모두 [+설정성] 자질 을 가지고 있으나/ㄹ, ㄴ/은 공명음, / ㅈ, 쪼, ㅊ/은 장애음으로(Shin \& Cha, 2003) 인접자음의 조음위치 분류에 이견이 있으므로 제외 하였다. 장애음과 비음이 연쇄되는 비단어도 장애음이 공명음의 영향을 받아 같은 조음위치의 비음으로 실현되므로 제외하였다 (Kim \& Shin, 2007).

위의 선정 기준을 적용하여 예비로 선정한 1 차 비단어 159 개의 실험과제로서의 타당성 확인을 위해 언어병리학 전공 석사수료생 6 명에게 159 개 비단어검사지를 주고각 비단어 발음 시 의미단어가 연상되는지, 음성적 유사성이 있는지 Likert 5 점 척도로 평정하게 하였다. 비단어라도 의미단어가 연상되거나 의미단어와 음운구조 가 유사할 경우 따라말하기 및 음운실현의 용이성에 영향을 미칠 수 있으므로 의미단어와의 음성적 유사성 점수가 낮게 판단된 105 개(5점 중 1-2점)를 2 차 예비 비단어로 선정하였다. 2 차 예비 비단어 105 개 중 어두 및 어중 초성 위치에 / ㅈ, ㅉ, 치,/ᄀ, T, ㅋ//,/人, 씨, /ㅎ/, 어중 및 어말 종성 위치에 / ᄀ, ᄂ, ㄹ, ㅁ, ㅂ, 이이 2, 3음절의 조음복잡성 저단어와 고단어에 고르게 분포되도록 하였다. 최종 선정된 비단어는 2 음절의 경우 조음복잡성 저단어 14 문항, 고단어 11 문항이었고, 3 음절의 경우 조음복잡성 저단어 14 문항, 고단어 11 문항으로 Appendix 1에 제시하였다.

\section{검사도구 제작}

최종적으로 선정된 비단어 50 문항을 검사자가 자연스럽게 발음 하도록 연습한 후 소음이 차단된 장소에서 음성 마이크(ATR2100- 
$\mathrm{USB}$ )를 사용하여 녹음하였다. 비단어 간 휴지간격은 $3,6,9$ 초로 달 리하여 음성파일을 제작하였다. 또한 아동이 충분히 이해하여 예 비검사에 참여할 수 있도록 지시문을 작성하여 동일하게 설명하였 고, 어린이용 헤드셋을 착용한 상태에서 비단어를 따라말하게 하 였다. 예비검사 결과를 토대로 검사 지시문을 수정하고, 청취 조건 을 어린이용 헤드셋에서 노트북 스피커로 변경하였으며, 비단어간 휴지간격은 6초로 결정하였다. 본 검사의 최종 검사도구 제작 시 비 단어 50 문항의 순서효과를 배제하기 위해 2,3 음절의 조음복잡성 저단어와 고단어가 무선으로 10 문항씩 제시되도록 편집한 음성파 일을 노트북 스피커로 들려주었다.

\section{연구절차}

녹음된 비단어 청취 자료를 듣고 따라 말하는 과제는 연구대상 아동이 재학하는 유치원과 어린이집에 방문하여 조용한 교실에서 검사자와 일대일 방식으로 실시하였다. 검사 지시문은 총 2 회 들려 주고 2개의 연습용 비단어를 듣고 연습하였다. 아동이 검사 절차를 이해하지 못한 경우 3 회까지 반복하였으며, 검사 진행이 어려운 아 동은 자료분석에서 제외하였다.

검사자는 아동에게 녹음된 비단어를 노트북 스피커를 이용하여 55-65 dB의 크기로 들려주었으며, 아동이 따라 말한 비단어는 스 탠드를 설치하여 아동의 입과 마이크(ATR2100-USB)의 거리가 일 정 정도 $(10 \mathrm{~cm})$ 유지되도록 녹음하였다. 녹음된 비단어는 한 번만 들려주며, 주변소음으로 인해 아동이 정확히 듣지 못한 것으로 판 단된 경우에는 검사 종료 후 해당 문항을 검사자가 입을 가리고 다 시 들려주어 따라 말하게 하였다.

\section{자료 분석 및 처리}

Ingram과 Ingram (2001)의 단어단위 음운 분석(phonological whole word analysis)을 Suk (2006)과 Park (2010)이 수정한 기준을 사용하여 단어 정확률, 단어 평균음운길이, 단어 근접률, 단어 변 이율을 산출하였으며, 단어 정확률, 단어 평균음운길이, 단어 근접 률은 3 회 반복한 단어 중 처음 듣고 시도한 음성형을 기준으로 분 석하였다. 본 연구는 한 단어를 기준으로 단어단위 지표를 구하였 기 때문에 기존의 단어 평균음운길이는 구할 수 없으므로 목표 단 어의 평균음운길이 값에 아동이 따라 말한 음성형의 평균음운길 이 값의 차이를 구하여 단어 평균음운길이차를 산출하였다. 단어 단위 지표의 유형별 분석방법은 다음과 같다.

단어 정확률 $(\mathrm{PWC})=$ 아동이 정반응한단어수 / 전체 검사단어 수

단어 평균음운길이차 $(\mathrm{DPMLU})=$ 목표 단어의 PMLU - 아동이 산출한 단어의 PMLU
단어 근접률 $(\mathrm{PWP})=$ 아동이 산출한 $\mathrm{PMLU} /$ 목표발음 $\mathrm{PMLU}$ 단어 변이율 $(\mathrm{PWV})=$ 아동이 산출한 단어 형태 수/해당 단어 반 복 횟수

아동이 따라 말할 때 보인 조음오류는 그 유형별로 오류빈도를 산출하였다. 조음오류 유형은 우리말 조음·음운평가(Urimal Test of Articulation and Phonology, U-TAP; Kim \& Shin, 2004)의 대치, 생략, 첨가 정의를 기준으로 분류하였다. 오류유형 분석 시 Hwang 과 $\mathrm{Ha}$ (2010)의 조음오류 유형 분석 방법을 참고하여 정확한 발음 과 정확한 발음은 아니나 목표음에 가깝게 산출된 경미한 왜곡은 정반응으로 처리하였고, 대치, 생략, 첨가는 오반응으로 처리하여 오류빈도를 산출하였다.

\section{자료분석}

통계처리는 PASW 18.0을 이용하였다. 조음복잡성(저/고)에 따 라 4 개의 단어단위 분석 지표에서 세 연령 집단 내와 집단 간에 차 이가 있는지 알아보기 위해 이원혼합분산분석(two-way mixed ANOVA)을 실시하였다. 각 연령 집단 내에서 조음복잡성 저단어 와 고단어에서의 단어단위 분석 지표별 차이의 유의성과 조음복잡 성 저/고단어에서 세 연령 집단 간의 단어단위 분석 지표별 차이의 유의성은 Scheffé 사후검증을 통해 확인하였다. 각 연령 집단의 조 음오류 유형별 출현빈도는 기술통계 분석을 실시하였다.

\section{신뢰도}

평가자 간 전사 신뢰도 분석을 위해 총 45 명 아동의 음성파일 중 각 연령 집단 별로 3 명씩 총 9 명을 임의로 추출하여 제 1 평가자인 제 1 저자와 임상경력 7 년 이상의 언어재활사 2 급 자격증을 소지한 제 2 평가자 1 명이 한글전사(간략전사)하여 산출한 신뢰도는 $92.8 \%$ 였 다. 이 중 4 세 전반, 4 세 후반, 5 세 전반 자료에 대한 전사 신뢰도는 각각 $91.5 \%, 93.3 \%, 93.5 \%$ 였다.

\section{연구결과}

\section{조음복잡성(저/고)에 따른 단어단위 분석 지표 유형별 결과}

조음복잡성(저/고)에 따른 단어단위 분석 지표(단어 정확률, 단 어 평균음운길이차, 단어 근접률, 단어 변이율 각각)의 기술통계는 Table 3에 제시하였다.

단어단위 분석 지표 유형 중 단어 정확률은 4 세 전반이 조음복 잡성 저단어에서 평균 $.80(\mathrm{SD}=.05)$, 고단어에서 평균 $.48(\mathrm{SD}=.09)$ 이었고, 4 세 후반이 조음복잡성 저단어에서 평균 $.90(\mathrm{SD}=.04)$, 고 
A Rum Kim, et al. • Phonological Characteristics in Nonword Repetition

Table 3. Descriptive statistics of whole-word measure index for phonetic complexity (low/high)

\begin{tabular}{|c|c|c|c|c|c|c|c|c|}
\hline \multirow{2}{*}{ Age group } & \multicolumn{2}{|c|}{ PWC } & \multicolumn{2}{|c|}{ DPMLU } & \multicolumn{2}{|c|}{ PWP } & \multicolumn{2}{|c|}{ PWV } \\
\hline & low PC & high PC & low PC & high PC & low PC & high PC & low PC & high PC \\
\hline $4 ; 0-4 ; 5(\mathrm{~N}=15)$ & $.80(.05)$ & $.48(.09)$ & 6.07 (1.98) & $18.80(6.17)$ & $.97(.00)$ & $.92(.02)$ & $.37(.02)$ & $.47(.06)$ \\
\hline $4 ; 6-4 ; 11(\mathrm{~N}=15)$ & $.90(.04)$ & $.65(.06)$ & $2.73(1.28)$ & $10.00(3.31)$ & $.98(.00)$ & $.95(.01)$ & $.35(.02)$ & $.41(.03)$ \\
\hline $5 ; 0-5 ; 5(\mathrm{~N}=15)$ & $.91(.03)$ & $.72(.04)$ & $2.13(1.18)$ & $8.13(1.80)$ & $.98(.00)$ & $.96(.00)$ & $.35(.02)$ & $.40(.02)$ \\
\hline Total score ( $\mathrm{N}=45$ ) & $.87(.06)$ & $.61(.12)$ & 3.64 (2.29) & $12.31(6.23)$ & $.98(.00)$ & $.94(.02)$ & $.36(.02)$ & $.43(.05)$ \\
\hline
\end{tabular}

Values are presented as mean (SD).

$\mathrm{PWC}=$ proportion of whole word correctness; DPMLU = difference in proportion mean length of utterance; PWP= proportion of whole word proximity; $\mathrm{PWV}=$ proportion of whole word variability; $\mathrm{PC}=$ phonetic complexity.
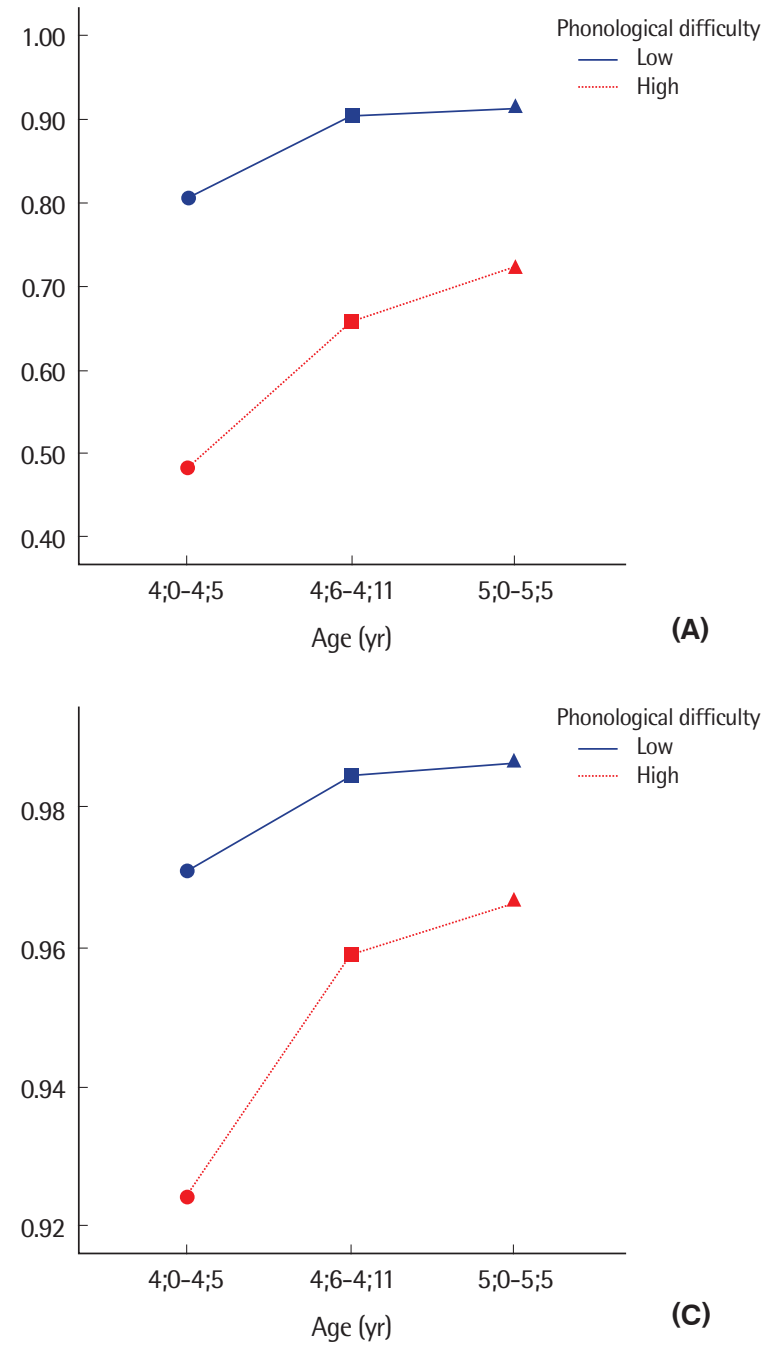
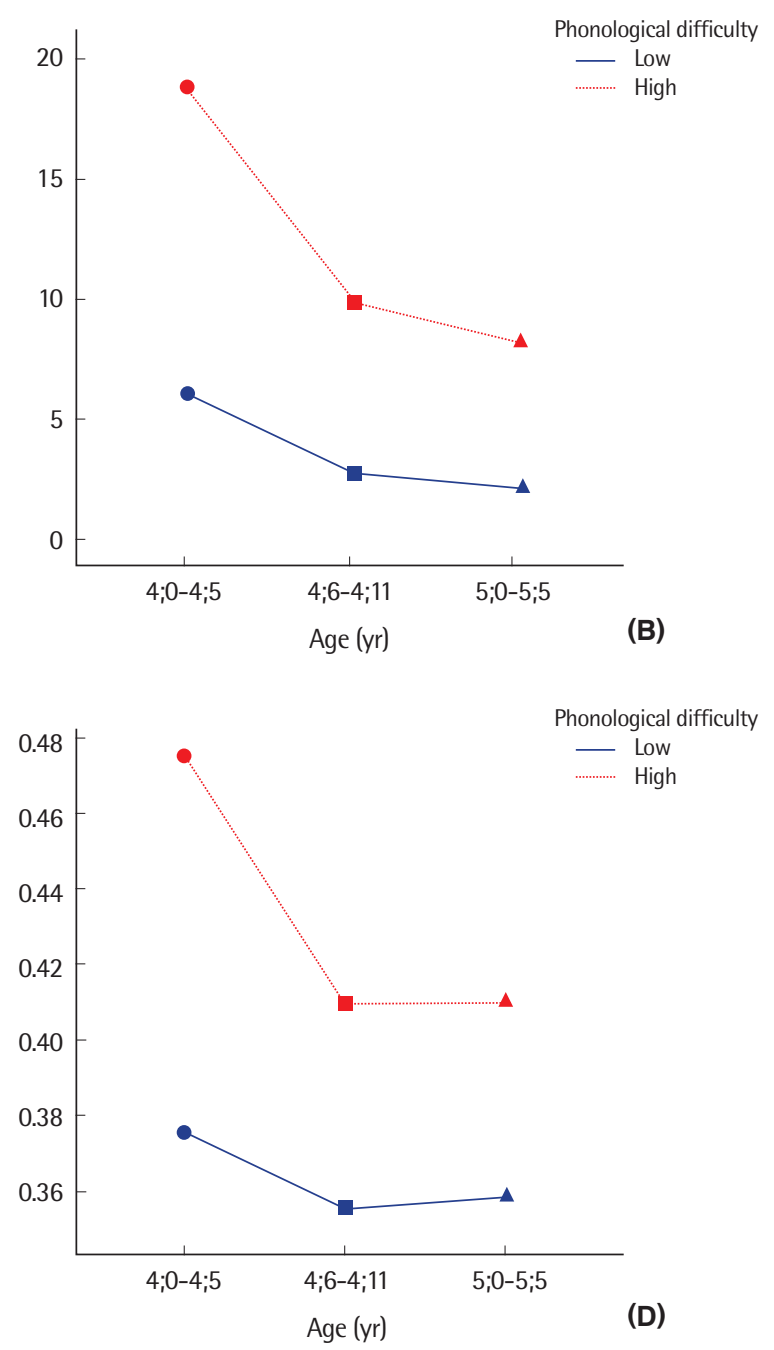

Figure 1. Interaction of age and phonetic complexity (low/high): (A) proportion of whole word correctness (PWC), (B) difference in proportion mean length of utterance (DPMLU), (C) proportion of whole word proximity (PWP), and (D) proportion of whole word variability (PWV).

단어에서 평균 $.65(\mathrm{SD}=.06), 5$ 세 전반이 조음복잡성 저단어에서 평균 .91 $(\mathrm{SD}=.03)$, 고단어에서 평균 .72 $(\mathrm{SD}=.04)$ 를 보였다. 조음 복잡성(저/고) 및 연령에 따라 단어 정확률에서 유의한차이가 있는
지 알아보기 위하여 이원혼합분산분석(two-way mixed ANOVA) 을 실시한 결과, 조음복잡성의 주효과 $\left(F_{(1,42)}=363.388, p<.001\right)$ 와 연령의 주효과 $\left(F_{(2,42)}=79.083, p<.001\right)$ 가 유의하였고, 조음복잡성 
과 연령의 상호작용 효과 $\left(F_{(2,42)}=8.439, p<.05\right)$ 도 유의하였다(Figure 1A). 이러한 차이가 어느 집단 대조에서 나타났는지 확인하기 위해 Scheffé 사후 검증을 실시한 결과, 세 연령 집단 모두 조음복잡 성 저단어와고단어에서 유의한단어 정확률차이를 보였다 $(p<.001)$. 또한, 조음복잡성 저단어에서는 4 세 전반과 4 세 후반 $(p<.001), 4$ 세 전반과 5 세 전반 $(p<.001)$, 고단어에서는 4 세 전반과 4 세 후반 $(p<$ $.001), 4$ 세 전반과 5 세 전반 $(p<.001), 4$ 세 후반과 5 세 전반의 대조 $(p<.05)$ 에서 단어 정확률의 차이가 유의하였다.

단어 평균음운길이차는 4 세 전반이 조음복잡성 저단어에서 평 균 $6.07(\mathrm{SD}=1.98)$, 고단어에서 평균 $18.80(\mathrm{SD}=6.17)$ 이었고, 4 세 후반이 조음복잡성 저단어에서 평균 $2.73(\mathrm{SD}=1.28)$, 고단어에서 평균 $10.00(\mathrm{SD}=3.31), 5$ 세 전반이 조음복잡성 저단어에서 평균 $2.13(\mathrm{SD}=1.18)$, 고단어에서 평균 $8.13(\mathrm{SD}=1.80)$ 을 보였다. 조음 복잡성의 주효과 $\left(F_{(1,42)}=150.085, p<.001\right)$ 와 연령의 주효과 $\left(F_{(2,42)}=\right.$ $53.621, p<.001)$ 가 유의하였고, 조음복잡성과 연령의 상호작용 효 과 $\left(F_{(2,42)}=8.528, p<.05\right)$ 도 유의하였다(Figure 1B). 세 연령 집단 모 두 조음복잡성 저단어와 고단어에서 보인 단어평균음운길이차가 유의하였다 $(p<.001)$. 또한, 조음복잡성 저단어와 고단어에서는 4 세 전반과 4 세 후반, 4 세 전반과 5 세 전반의 대조에서 단어 평균음 운길이차의 차이가 유의하였다 $(p<.001)$.

단어 근접률은 4 세 전반이 조음복잡성 저단어에서 평균 $.97(\mathrm{SD}=$ $.00)$, 고단어에서 평균 $.92(\mathrm{SD}=.02)$ 이었고, 4 세 후반이 조음복잡 성 저단어에서 평균 $.98(\mathrm{SD}=.00)$, 고단어에서 평균 $.95(\mathrm{SD}=.01)$, 5 세 전반이 조음복잡성 저단어에서 평균 $.98(\mathrm{SD}=.00)$, 고단어에 서 평균.96 $(\mathrm{SD}=.00)$ 을 보였다. 조음복잡성의 주효과 $\left(F_{(1,42)}=135.654\right.$, $p<.001)$ 와 연령의 주효과 $\left(F_{(2,42)}=53.771, p<.001\right)$ 가 유의하였고, 조음복잡성과 연령의 상호작용 효과 $\left(F_{(2,42)}=9.275, p<.001\right)$ 도 유 의하였다(Figure $1 \mathrm{C}$ ). 단어 근접률에서도 세 연령 집단 모두 조음 복잡성 저단어와 고단어에서 유의한 차이를 보였다 $(p<.001)$. 조음 복잡성 저단어와 고단어에서는 4 세 전반과 4 세 후반, 4 세 전반과 5 세 전반의 대조에서 단어 근접률의 차이가 유의하였다 $(p<.001)$.

단어 변이율은 4 세 전반이 조음복잡성 저단어에서 평균. $37(\mathrm{SD}=$
.02), 고단어에서 평균 $.47(\mathrm{SD}=.06)$ 이었고, 4 세 후반이 조음복잡성 저단어에서 평균 $.35(\mathrm{SD}=.02)$, 고단어에서 평균 $.41(\mathrm{SD}=.03), 5$ 세 전반이 조음복잡성 저단어에서 평균 $.35(\mathrm{SD}=.02)$, 고단어에서 평 균 .40 $(\mathrm{SD}=.02)$ 을 보였다. 조음복잡성의 주효과 $\left(F_{(1,42)}=105.189\right.$, $p<.001)$ 와 연령의 주효과 $\left(F_{(2,42)}=10.097, p<.001\right)$ 가 유의하였고, 조음복잡성과 연령의 상호작용 효과 $\left(F_{(2,42)}=5.482, p<.01\right)$ 도 유의 하였다(Figure $1 \mathrm{D})$. 세 연령 집단 모두 조음복잡성 저단어와 고단 어에서 유의한 단어 변이율 차이를 보였다 $(p<.001)$. 또한, 조음복 잡성 고단어에서는 4 세 전반과 4 세 후반, 4 세 전반과 5 세 전반의 대 조에서 단어 변이율의 차이가 유의하였으나 $(p<.01)$, 조음복잡성 저단어에서는 연령 집단 간에 유의한 차이가 나타나지 않았다.

\section{조음복잡성(저/고)에 따른 조음오류 유형별 출현빈도}

조음복잡성(저/고)에 따른 조음오류 유형별 출현빈도의 기술통 계는 Table 4에 제시하였다. 4 세 전반은 조음복잡성 저단어에서 평 균 1.59회(SD=.84), 고단어에서 평균 3.17회( $\mathrm{SD}=2.15), 4$ 세 후반 은 조음복잡성 저단어에서 평균 1.14 회 $(\mathrm{SD}=.59)$, 고단어에서 평균 2.17 회 $(\mathrm{SD}=1.84), 5$ 세 전반은 조음복잡성 저단어에서 평균 .90회 ( $\mathrm{SD}=.70)$, 고단어에서 평균 1.83 회( $\mathrm{SD}=1.31)$ 의 조음오류를 보여 조음복잡성 저단어보다 고단어에서 조음오류를 더 많이 보이는 경 향이 있었다. 연령 집단 간 조음오류 출현빈도에서 나타난 경향을 살펴보면 4세 전반이 가장 빈번하게 조음오류를 보였으며, 4 세 후 반과 5세 전반은 조음복잡성 고단어에서는 조음오류가 빈번하였 으나 조음복잡성 저단어에서는 조음오류가 감소하였다. 조음오류 유형별 출현빈도에서 나타난 경향을 살펴보면 대치, 생략, 첨가 중 대치가 조음복잡성 저단어에서 평균 1.84 회 $(\mathrm{SD}=.58)$, 고단어에서 평균 4.38 회 $(\mathrm{SD}=1.08)$ 로 가장 높은 빈도로 출현하였다. 생략은 조 음복잡성 저단어에서 평균 .67 회 $(\mathrm{SD}=.64)$, 고단어에서 평균 1.71 회( $\mathrm{SD}=.91)$, 첨가는 조음복잡성 저단어에서 평균 1.12회( $\mathrm{SD}=.33)$, 고단어에서 평균 1.08 회 $(\mathrm{SD}=.14)$ 로 나타났으며, 첨가가 가장 낮은 빈도로 출현하였다.

Table 4. Frequency of articulation error type for phonetic complexity (low/high)

\begin{tabular}{|c|c|c|c|c|c|c|c|c|}
\hline \multirow{2}{*}{ Age group } & \multicolumn{4}{|c|}{ low PC } & \multicolumn{4}{|c|}{ high PC } \\
\hline & Substitution & Omission & Addition & Total & Substitution & Omission & Addition & Total \\
\hline $4 ; 0-4 ; 5(N=15)$ & $2.52(1.61)$ & $1.40(.69)$ & $.87(.35)$ & $1.59(.84)$ & $5.51(3.65)$ & $2.77(1.92)$ & $1.25(.50)$ & $3.17(2.15)$ \\
\hline $4 ; 6-4 ; 11(\mathrm{~N}=15)$ & $1.47(.69)$ & $.46(.51)$ & $1.50(.70)$ & $1.14(.59)$ & $4.30(2.94)$ & $1.22(.73)$ & $1.00(.00)$ & $2.17(1.84)$ \\
\hline $5 ; 0-5 ; 5(N=15)$ & $1.55(.61)$ & $.16(.38)$ & $1.00(.00)$ & $.90(.70)$ & $3.35(2.36)$ & $1.16(.83)$ & $1.00(.00)$ & $1.83(1.31)$ \\
\hline Total score ( $\mathrm{N}=45)$ & $1.84(.58)$ & $.67(.64)$ & $1.12(.33)$ & $1.21(.35)$ & $4.38(1.08)$ & $1.71(.91)$ & $1.08(.14)$ & $2.39(.69)$ \\
\hline
\end{tabular}

Values are presented as mean (SD).

$\mathrm{PC}=$ phonetic complexity. 


\section{논의 및 결론}

단어의 복잡한 음운구조는 단어 내 개별 음소의 산출을 어렵게 만들 뿐만 아니라 단어 전체의 조음에 영향을 미칠 수 있다. 따라서 본 연구는 말소리 발달의 안정기에 해당하는 만 4 세 전반, 4 세 후 반, 5 세 전반의 일반아동 15 명씩, 총 45 명을 대상으로 조음복잡성 을 달리 고려하여 제작한 비단어 따라말하기에서 나타난 단어단위 음운 특성(단어 정확률, 단어 평균음운길이차, 단어 근접률, 단어 변이율)과 조음오류 유형별 출현빈도를 살펴봄으로써 조음복잡성 이 비단어 따라말하기 과제에서 나타난 조음에 미치는 영향을 알 아보고자 하였다.

먼저 조음복잡성(저/고)에 따른 단어단위 음운 특성을 살펴본 결과, 단어단위 분석 지표로 적용한 단어 정확률, 단어 평균음운길 이차, 단어 근접률, 단어 변이율 모두에서 조음복잡성 및 연령의 주 효과가 유의하였으며, 조음복잡성과 연령의 상호작용 효과도 유의 하였다. 세 연령 집단은 모두 조음복잡성 저단어보다 고단어에서 더 낮은 단어 정확률과 단어 근접률을 보였고, 더 높은 단어 평균 음운길이차와 단어 변이율을 보였다. 또한, 조음복잡성 저단어와 고단어에서 모두 4 세 전반에서 5 세 전반으로 갈수록 더 높아지는 단어 정확률과 단어 근접률, 더 낮아지는 단어 평균음운길이차와 단어 변이율을 보였다. 조음복잡성 저단어와 고단어의 4 개의 모든 단어단위 지표에서 유의한 차이를 보인 연령 집단 대조는 4 세 전반 과 4 세 후반, 4 세 전반과 5 세 전반이었으며, 4 세 후반과 5 세 전반은 조음복잡성 고단어의 단어 정확률에서도 유의한 차이를 보였다. 그러나 조음복잡성 저단어의 단어 변이율은 연령 집단 간 차이가 유의하지 않았다. 이러한 결과를 통해 조음복잡성이 아동의 단어 단위 음운 특성을 파악하는 데에도 유용한 변수임을 알 수 있다. 즉, 단어단위 분석 지표는 음운발달 초기의 아동뿐만 아니라 단어 의 의미적 복잡성과 조음복잡성을 고려한다면 4-5세 아동의 음운 평가에도 유용할 수 있다. 단어단위 분석 지표별 결과를 세부적으 로 살펴보면 다음과 같다.

조음복잡성 저단어와 고단어에서 모든 연령 집단 대조에서 유의 한 차이가 나타난 단어 정확률은 연령이 높아짐에 따라 단어 정확 률이 증가한다는 선행연구 결과와 일치하며(Park \& Suk, 2012; Suk, 2006), 단어 정확률이 음운 평가 시 효과적인 지표일 수 있다는 선 행연구 결과를 지지한다(Park, 2015). 단어 평균음운길이차가 조 음복잡성 저단어와 고단어에서 4 세 전반과 4 세 후반, 4 세 전반과 5 세 전반 연령 집단 간에 유의한 차이를 보인 결과는 연령이 높아짐 에 따라 목표 단어의 평균음운길이와 아동이 따라 말한 음성형의 평균음운길이 점수의 차이가 감소한 결과이다. 이는 연령이 높아
짐에 따라 단어 평균음운길이가 증가하였다는 선행연구(Park \& Suk, 2012; Suk, 2006)를 지지한다고 볼 수 있다. 단어 평균음운길 이차와 동일하게 조음복잡성 저단어와 고단어에서 4 세 전반과 4 세 후반, 4 세 전반과 5 세 전반 연령 간에 유의한 차이를 보인 단어 근 접률은 2-4세 일반아동을 대상으로 단어단위 분석을 실시하여 연 령이 높아짐에 따라 단어 근접률이 증가함을 보고한 Park과 Suk (2012)의 연구결과를 지지한다. 그러나 3-5세 아동을 1년 단위로 구 분하여 놀이상황에서 수집한 아동의 발화샘플을 통해 단어단위 분석을 실시한 Suk (2006)과 5-7세 일반아동을 1년 단위로 구분하 여 단어단위 분석을 실시한 Park과 Son (2012)의 연구결과에서는 연령 집단 간의 차이가 유의한 것으로 나타났으나 본 연구에서는 4 세 후반과 5 세 전반 사이에서는 차이가 나타나지 않았다. 이러한 결 과의 차이는 연구 과제의 차이로 해석할 수도 있으나 아동이 4 세 후반 이후 목표단어 즉 성인의 발음에 근접하게 단어를 산출한 결 과로 볼 수 있다. 마지막으로 조음복잡성 고단어에서는 4 세 전반과 4 세 후반, 4 세 전반과 5 세 전반이 유의한 차이를 보인 반면, 저단어 에서는 집단 간 차이가 나타나지 않은 단어 변이율은 높은 조음복 잡성 점수가 단어 변이율에 영향을 미쳤거나 조음복잡성이 낮은 단어의 경우 4 세에 이미 안정적인 조음 수행을 보이기 때문으로 해 석할 수 있다. 그러나 이러한 결과는 연령이 높아질수록 안정적인 조음 수행으로 인해 단어 변이율이 감소하고, 4 세 전반과 4 세 후반 간 단어 변이율의 차이가 나타나지 않았다는 선행연구 결과(Park \& Suk, 2012; Hwang \& Ha, 2012)와는 부분적으로 불일치한다. 이 는 의미단어를 활용하여 단어단위 분석을 실시한 선행연구와 달리 본 연구에서는 추가로 전반적인 조음복잡성지표를 고려한 비단어 따라말하기를 활용하여 비단어의 조음복잡성 정도에 따라 단어단 위 분석을 실시한 결과라고 할 수 있다. 또한, Hwang과 $\mathrm{Ha}$ (2012) 의 연구에서는 아동이 그림을 보면서 의미단어 수준과 문장 수준 에서 목표단어를 각 4 회씩 자발적으로 산출하도록 유도하였다. 그 러나 본 연구에서는 비단어를 들려주고 아동이 세 번씩 연속하여 산출하게 유도하였다. 아동이 비단어를 연속적으로 따라 말하는 방법은 조음의 일관성이 유지되는 부분에 영향을 미쳤을 것으로 추정된다.

둘째, 조음복잡성(저/고)에 따른 조음오류 유형별 출현빈도는 조 음복잡성 저단어보다 고단어에서 높았고, 만 4 세 전반이 가장 빈번 한 조음오류를 보였고, 4 세 후반, 5 세 전반 순으로 낮아지는 경향을 보였다. 또한 4 세 후반과 5 세 전반은 4 세 전반에 비해 조음복잡성 저단어에서 조음오류가 감소하였으나 고단어에서는 지속적으로 빈번한 조음오류를 보였다. 조음오류 유형은 조음복잡성 저단어와 고단어에서 모두 대치가 가장 높았으며, 생략, 첨가 순으로 낮아지 
는 경향을 보였다. 이러한 결과는 조음복잡성이 높은 단어에서 조 음오류 출현율이 높다는 연구결과와 일치하며(Shin \& $\mathrm{Ha}, 2015)$, 연령이 높아짐에 따라 음운변동이 사라진다고 보고한 Kim (1992), Hwang와 Ha (2012)의 연구결과를 지지한다. 추가적으로 조음복 잡성 저단어와 고단어에서 나타난 조음오류를 조음복잡성지표에 근거하여 살펴보았을 때, 자음이 연쇄되어있는 단어(지표 6)에서 조음오류의 빈도가 가장 높았으며 동일조음위치의 자음연쇄(지표 7), 어절의 길이(지표 5), 자음의 조음방법(지표 2) 순으로 조음오류 출현빈도가 낮아지는 경향을 보였다. 개별 음소의 특성보다는 단 어 전체의 음운구조가 갖는 조음복잡성이 조음오류에 영향을 미 친다고 볼 수 있으므로 조음 평가나 치료 시 조음복잡성을 고려한 단어 선정과 분석이 필요함을 알 수 있다.

본 연구는 의미적 복잡성은 통제하고 조음복잡성(저/고)에 따라 의미단어와 유사하게 고안한 비단어를 이용하여서도 말소리 발달 의 안정기에 해당하는 4-5세 아동들을 대상으로 단어단위 분석지 표가 비단어 전체뿐만 아니라 단어 내 개별 음소의 산출에 미치는 영향을 파악하는 데 유용함을 입증한 데 그 의의가 있다. 언어적 배 경지식을 통제한 채 조음복잡성이 조음에 미치는 영향을 알아보 기 위해 전반적인 조음복잡성지표를 활용하여 의미상으로는 비단 어이나 우리말에서 나타날 수 있는 음운 형태를 고려하여 우리말 처럼 들리는 유사단어를 제작하였으나 한국어에 가장 많은 2-3음 절로 어절의 길이를 제한하였다. 조음복잡성지표 체계 및 배점 기 준의 지표 5 인 어절의 길이의 배점 기준을 살펴보면, 1 점은 $1-2$ 음절, 2점은 3음절 이상으로 점수를 부여하고 있으므로 후속 연구에서 는 한국어 특성을 고려하여 다양한 길이의 단어 또는 비단어를 고 안해야 할 것이다. 한국어 말소리의 출현 빈도와 음운 - 음성적 특 성을 고려하여 3음절의 조음복잡성 고단어 제작 시 12-15점의 비 단어를 제작하여 다른 비단어 목록의 수와 균형을 맞추고자 형태 적으로 유사한 비단어를 최종 선정하여 비단어 따라말하기 과제 를 실시하였다. 추후 연구에서는 3음절의 조음복잡성 고단어 제작 시 비단어 간의 유사성을 최소화하기 위한 노력이 필요할 것이다. 또한, 음운 및 음성적 특성에 따라 말소리 처리과정이 다를 수 있으 며, 비단어 따라말하기 과제는 음향신호 지각, 언어처리, 말산출 능 력의 협응 등이 요구되나 이를 사전에 전반적으로 고려하지 못하여 본 연구 결과를 조음복잡성으로 인한 결과로 일반화하여 해석하 는 데에는 무리가 있다. 따라서 추후 연구에서는 조음복잡성의 영 향을 밝히기 위하여 비단어 따라말하기 과제의 특성을 반영하여 연구를 실시해야 하며, 동일한 조음복잡성을 가지는 비단어와 의 미단어 따라말하기에서 나타나는 음운 특성을 알아보기 위한 연 구가 이루어져야 할 것이다. 마지막으로 본 연구 대상자 선정 시 말
지각능력, 음운 단기기억력 등의 변인을 통제하지 못하였으며, 조음 발달에서 완전숙달연령에 해당되는 만 5세 후반에서 6세 전반을 연구대상에 포함시키지 못하여 말소리 발달의 전 과정에서의 발달 적 추이를 살펴보지 못하였다. 최초 연구 계획에서는 말소리가 역 동적으로 발달하는 만 3-5세 아동을 연구 대상으로 선정하였다. 2 세 아동은 비단어 따라말하기 과제가 어려울 것으로 생각되어 처 음부터 대상에서 제외하였다. 그러나 예비연구에서 만 3세 전반, 3 세 후반 아동도 비단어 따라말하기 과제 수행에 어려움을 호소하 여 최종 데이터에서 제외하였고, 말소리 습득이 안정화되는 만 4 세 전반, 4세 후반, 5 세 전반 아동만을 연구 대상으로 선정하였다. 따 라서 추후 연구에서는 연구 대상자 선정 시 말 산출에 영향을 미칠 수 있는 변인을 사전에 최대한 통제하여 다양한 연령을 대상으로 조음복잡성에 따른 비단어 따라말하기에서 나타나는 음운 특성 을 살펴볼 필요가 있다.

\section{REFERENCES}

An, Y. S. (2012). Characteristics of nonword repetition performance and disfluency in preschool-age children who stutter according to phonological complexity (Master's thesis). Ewha Womans University, Seoul, Korea.

Bae, J. C. (2014). Korean vocabulary and dictionaries. Paju: Thaehaksa.

Chon, H. C., \& Ambrose, N. (2016). A preliminary study of the non-word repetition abilities of children with persistent and recovered stuttering. Journal of Speech-Language \& Hearing Disorders, 25, 211-222.

Dworzynski, K., \& Howell, P. (2004). Predicting stuttering from phonetic complexity in german. Journal of Fluency Disorders, 29, 149-173.

Ha, S., \& Hwang, J. (2013). Speech measures from phonological analyses of spontaneous conversations in children between 18-47 months of age. Communication Sciences \& Disorders, 18, 425-434.

Hwang, J., \& Ha, S. (2010). Nonword repetitions of 2-to 5-year-old typically developing children. Korean Journal of Communication Disorders, 15, 561571.

Hwang, J., \& Ha, S. (2012). A study of articulatory variation in typically developing children between 2 and 4 years of age. Korean Journal of Communication Disorders, 17, 403-413.

Hwang, M. (2015). Nonword repetition of typically developing children. Communication Sciences \& Disorders, 20, 374-385.

Ingram, D., \& Ingram, K. D. (2001). A whole-word approach to phonological analysis and intervention. Language, Speech and Hearing Services in Schools, $32,271-283$. 
Kim, H. Y., \& Ha, S. (2016). Articulatory variability in 24- to 36-month-old typically developing children. Communication Sciences \& Disorders, 21, 333-342.

Kim, M. J. (2005). The development of the Korean Test of Articulation for Children (Doctoral dissertation). Yonsei University, Seoul, Korea.

Kim, M. J., \& Pae, S. (2005). The percentage of consonants correct and the ages of consonantal acquisition for 'Korean - Test of Articulation for Children (K-TAC)'. Speech Science, 12, 139-149.

Kim, M. J., Pae, S., \& Park, C. I. (2007). Assessment of Phonology and Articulation for Children (APAC). Incheon: Human Brain Research \& Consulting.

Kim, S. J. (2010). Syllable-final consonant error patterns of children with phonological disorders. Communication Sciences and Disorders, 15, 549-560.

Kim, S. J. (2012). Coda error patterns at word-medial position for 3 to 4 year old children. Korean Journal of Communication Disorders, 17, 177-186.

Kim, S. J., \& Shin, J. Y. (2007). Articulatory and phonological disorders. Seoul: Sigmapress.

Kim, S. J., \& Shin, J. Y. (2015). Speech sound disorders. Seoul: Sigmapress.

Kim, Y. E., Choi, S. E., \& Park, S. H. (2006). Phonological analysis of phonological disorders and normal children by whole-word approach. Speech Sciences, 13, 143-155.

Kim, Y. T. (1992). A study of phonological regression in 2-6 years of age: Omission and addition patterns. Journal of Rehabilitation Science, 10, 49-57.

Kim, Y. T., \& Shin, M. J. (2004). Urimal Test of Articulation and Phonology (U-TAP). Seoul: Hakjisa.

Kim, Y. T., Hong, K. H., Kim, K. H., Jang, H. S., \& Lee, J. Y. (2009). Receptive \& expressive vocabulary test (REVT). Seoul: Seoul Community Rehabilitation Center.

Lee, E. J., \& Sim, H. S. (2003). Phonological memory in the nonword repetition of children: a comparison of functional phonologically disordered and normal children. Korean Journal of Communication Disorders, 8, 127145.

Lee, E. J., Han, J. S., \& Sim, H. S. (2004). The effects of the phonetic complexity on the disfluencies and the articulation errors of people who stutter. Korean Journal of Communication Disorders, 9, 139-156.
Oh, D. Y., \& Yim, D. (2013). Non-word repetition and sentence repetition performance in 2-3 years old late talkers and normal children. Communication Sciences \& Disorders, 18, 277-287.

Park, H. (2010). Phonological whole-word measures in 2-4 years old children (Doctoral dissertation). Daegu University, Gyeongsan, Korea.

Park, H. J. (2015). Phonological characteristics according to the severity of articulation-phonological disorders through phonological whole-word analysis. Journal of Speech-Language \& Hearing Disorders, 24, 95-102.

Park, H., \& Son, E. N. (2012). A study of the phonological characteristics of pre-school children by measures of whole-words. Journal of Speech \& Hearing Disorders, 21, 19-34.

Park, H., \& Suk, D. I. (2012). Phonological whole-word measures in children aged 2 to 4 years. Journal of Speech \& Hearing Disorders, 21, 53-70.

Shin, G. E., \& Ha, J. W. (2015). The effects of phonetic complexity on the disfluency and articulation errors of children with speech sound disorders. Journal of Speech-Language \& Hearing Disorders, 24, 91-102.

Shin, H. J., \& Lee, E. J. (2015). Phonological characteristics of late-talkers through phonological whole-word analysis. Communication Sciences and Disorders, 20, 157-165.

Shin, J. Y. (2005). Bi-phoneme frequency of Korean: based on spontaneous speech of 3 to 8-year-old Korean children. The Association for Korean Linguistics, 28, 81-109.

Shin, J. Y. (2008). Bi-phoneme frequencies of Korean based on the analysis of spontaneous speech data. Korean Journal of Communication Disorders, 13, 477-502.

Shin, J. Y., \& Cha, J. E. (2003). Sound pattern of Korean. Seoul: Hankookmunhwasa.

Suk, D. I. (2004). A whole-word approach to phonological analysis with phonological disorders. Journal of Special Education: Theory and Practice, 5, 87-102.

Suk, D. I. (2006). A whole-word approach to phonological analysis with normal children aged from 3 to 5 years. Journal of Speech \& Hearing Disorders, 15, 15-28. 
Appendix 1. The list of nonwords

\begin{tabular}{|c|c|c|c|c|c|c|}
\hline \multicolumn{7}{|c|}{ 2음절 비단어 } \\
\hline \multirow{2}{*}{ 순번 } & \multicolumn{3}{|c|}{ 조음복잡성 점수 1-2점(저) } & \multicolumn{3}{|c|}{ 조음복잡성 점수 7-9점(고) } \\
\hline & 점수 & 비단어 & IPC & 점수 & 비단어 & IPC \\
\hline 1 & 1 & 구노 & 1 & 9 & 격쫄 & $1,2,3,4,6,7$ \\
\hline 2 & 1 & 너씨 & 2 & 9 & 척짤 & $1,2,4,6,7$ \\
\hline 3 & 1 & 며나 & 3 & 8 & 젱(쟁)벽 & $1,2,3,4,6,7$ \\
\hline 4 & 1 & 머납 & 4 & 8 & 셍(생)찰 & $1,2,4,6,7$ \\
\hline 5 & 1 & 넘베(배) & 6 & 7 & 격썸 & $1,2,3,4,6,7$ \\
\hline 6 & 2 & 케(캐)싸 & 1,2 & 7 & 혈씅 & $1,2,3,4,6$ \\
\hline 7 & 2 & 부교 & 1,3 & 7 & 쫑걱 & $1,2,4,6$ \\
\hline 8 & 2 & 가돈 & 1,4 & 7 & 족썬 & $1,2,4,6,7$ \\
\hline 9 & 2 & 혀타 & 2,3 & 7 & 찰교 & $1,2,3,6,7$ \\
\hline 10 & 2 & 미놀 & 2,4 & 7 & 경껙(깩) & $1,3,4,6$ \\
\hline 11 & 2 & 더면 & 3,4 & 7 & 혈썰 & $2,3,4,6$ \\
\hline 12 & 2 & 면떼(때) & 3,6 & & & \\
\hline 13 & 2 & 벤(밴)땁 & 4,6 & & & \\
\hline 14 & 2 & 딤너 & 6,7 & & & \\
\hline \multicolumn{7}{|c|}{ 3음절 비단어 } \\
\hline \multirow{2}{*}{ 순번 } & \multicolumn{3}{|c|}{ 조음복잡성 점수 1-2점(저) } & \multicolumn{3}{|c|}{ 조음복잡성 점수 12-15점(고) } \\
\hline & 점수 & 비단어 & IPC & 점수 & 비단어 & IPC \\
\hline 1 & 1 & 네(내)마고 & 1,5 & 15 & 형척짤 & $1,2,3,4,5,6,7$ \\
\hline 2 & 1 & 노수메(매) & 2,5 & 15 & 징착쩔 & $1,2,4,5,6,7$ \\
\hline 3 & 1 & 며보데(대) & 3,5 & 14 & 형철깍 & $1,2,3,4,5,6,7$ \\
\hline 4 & 1 & 마너덤 & 4,5 & 14 & 잘꼭짤 & $1,2,4,5,6,7$ \\
\hline 5 & 1 & 본또미 & 6,5 & 13 & 혈꼭썽 & $1,2,3,4,5,6,7$ \\
\hline 6 & 2 & 기나수 & $1,2,5$ & 13 & 설꺽쫑 & $1,2,4,5,6,7$ \\
\hline 7 & 2 & 겨도바 & $1,3,5$ & 13 & 혁절꾜 & $1,2,3,5,6,7$ \\
\hline 8 & 2 & 미두냉 & $1,4,5$ & 12 & 혁쑬꼼 & $1,2,3,4,5,6,7$ \\
\hline 9 & 2 & 혀마노 & $2,3,5$ & 12 & 강썸짝 & $1,2,4,5,6,7$ \\
\hline 10 & 2 & 수너던 & $2,4,5$ & 12 & 장싹쩌 & $1,2,5,6,7$ \\
\hline 11 & 2 & 며나돔 & $3,4,5$ & 12 & 경꽁멱 & $1,3,4,5,6,7$ \\
\hline 12 & 2 & 면뜨누 & $3,6,5$ & & & \\
\hline 13 & 2 & 비던땁 & $4,6,5$ & & & \\
\hline 14 & 2 & 담누파 & $6,7,5$ & & & \\
\hline
\end{tabular}




\title{
국문초록
}

\author{
조음복잡성에 따른 비단어 따라말하기에서 나타난 4-5세 일반아동의 음운 특성 \\ 김아름 ${ }^{1}$ 이 란 ${ }^{1}$ 한진순 $\cdot$ 이은주 ${ }^{2}$ \\ '단국대학교 대학원 언어병리학과, ${ }^{2}$ 단국대학교 특수교육과
}

배경 및 목적: 조음복잡성이 음운 특성과 조음오류에 미치는 영향을 알아보기 위하여 조음복잡성이 높은 비단어와 낮은 비단어 따라 말하기를 통해 단어단위 음운 특성과 조음오류 유형별 빈도를 살펴보았다. 방법: 4 세 전반, 4 세 후반, 5 세 전반, 총 45 명의 일반아동을 대상으로 50 개의 비단어 따라말하기를 실시하였다. 조음복잡성 점수(저/고)에 따른 단어단위 분석 지표(단어 정확률, 단어 평균음운 길이차, 단어 근접률, 단어 변이율)와 조음오류 유형별 출현빈도에서 나타난 연령 집단별 특성을 살펴보았다. 결과: 조음복잡성과 연령 에 따라 단어단위 분석 지표에서 차이가 유의하였으며, 조음복잡성과 연령의 상호작용 효과도 유의하였다. 조음복잡성 저단어와 고단 어에서 모든 단어단위 분석 지표의 차이가 유의하였으며 4 세 전반과 4 세 후반, 4 세 전반과 5 세 전반은 조음복잡성 저단어와 고단어에 서 유의한 단어단위 지표 차이를 보였다. 단어 정확률에서의 차이는 4 세 후반과 5 세 전반에서도 유의하였으나, 단어 변이율에서는 조 음복잡성 저단어에서 연령 집단 간 차이가 유의하지 않았다. 조음오류 유형별 출현빈도는 조음복잡성 저단어보다 고단어에서 높았으 며, 4 세 전반에서 가장 높았고, 4 세 후반, 5 세 전반 순으로 낮아지는 경향을 보였다. 조음오류 유형별 출현빈도는 대치가 가장 많았으며, 생략, 첨가 순으로 나타났다. 논의 및 결론: 조음복잡성 고단어에서 조음오류의 빈도가 높다는 선행연구 결과를 지지하고, 임상에서 조 음 평가 및 중재 시 조음복잡성을 고려한 어휘 선정이 필요함을 보여준다.

핵심어: 조음복잡성, 단어단위 음운 분석, 비단어 따라말하기

본 논문은 제1저자의 석사학위논문을 수정·보완한 것임.

\section{참고문헌}

김민정(2005). 아동용 한국어 조음검사의 개발. 연세대학교 대학원 박사학위논문.

김민정, 배소영(2005). '아동용조음검사를 이용한 연령별 자음정확도와 우리말 자음의 습득연령·음성과학, 12, 139-149.

김민정, 배소영, 박창일(2007). 아동용 발음평가검사(APAC). 인천: 휴브알앤씨.

김수진(2010). 기능적 조음음운장애 아동의 종성 음운변동 분석. 언어청각장애연구, $15,549-560$.

김수진(2012). 어중 두 자음 연쇄 조건에서 나타나는 3-4세 아동의 종성 발달. 언어청각장애연구, 17, 177-186.

김수진, 신지영(2007). 조음음운장애. 서울: 시그마프레스.

김수진, 신지영(2015). 말소리장애. 서울: 시그마프레스.

김영은, 최성은, 박상희(2006). 단어단위 접근법을 이용한 음운장애 아동과 정상아동의 음운 분석. 음성과학, 13, 143-155.

김영태(1992). 2-6세 아동의 음운변동에 관한 연구(I): 생략 및 첨가 변동을 중심으로. 재활과학연구, 10, 49-57.

김영태, 신문자(2004). 우리말 조음음운 평가(U-TAP). 서울: 학지사.

김영태, 홍경훈, 김경희, 장혜성, 이주연(2009). 수용·표현어휘력검사. 서울: 서울장애인종합복지관.

김희윤, 하승희(2016). 24-36개월 아동의 조음 변이성 연구. 언어청각장애연구, 21, 333-342.

박현(2010). 단어단위분석에 의한 2-4세 아동의 조음음운 특성연구. 대구대학교 대학원 박사학위논문.

박현, 석동일(2012). 단어단위 분석에 의한 2-4세 아동의 조음음운 특성 연구. 언어치료연구, 21, 53-70.

박현, 손은남(2012). 단어단위 음운 분석을 통한 취학 전 아동들의 음운 특성 연구. 언어치료연구, 21, 19-34.

박희정(2015). 중증도에 따른 조음음운장애 아동들의 단어단위 음운특성. 언어치료연구, 24, 95-102.

배주채(2014). 한국어의 어휘와사전. 파주: 태학사. 
석동일(2006). 단어단위 접근법에 의한 3-5세 유아의 음운특성 분석. 언어치료연구, 15, 15-28.

석동일(2004). 단어단위 접근법에 의한 조음음운장애 아동의 음운분석. 특수교육저널: 이론과 실천, 5, 87-102.

신가은, 하지완(2015). 말소리장애 아동의 조음복잡성에 따른 비유창성 및 조음오류 특성. 언어치료연구, 24, 91-102.

신지영(2005). 한국어 음소의 전이 빈도: 3 세-8세 아동의 자유 발화 자료를 바탕으로. 한국어학, 28, 81-109.

신지영(2008). 성인 자유 발화 자료 분석을 바탕으로 한 한국어의 음소 전이 빈도. 언어청각장애연구, 13, 477-502.

신지영, 차재은(2003). 우리말 소리의 체계: 국어음운론 연구의 기초를 위하여. 서울: 한국문화사.

신화정, 이은주(2015). 단어단위 음운분석에 의한 말 늦은 아동의 음운 특성. 언어청각장애연구, 20, 157-165.

안영순(2012). 학령전기 말더듬 아동의 조음복잡성에 따른 비단어 따라말하기 수행 및 비유창성 특성. 이화여자대학교 대학원 석사학위논문.

오다연, 임동선(2013). 2-3세 말 늦은 아동과 정상 아동의 비단어 따라말하기와 문장 따라말하기 수행 능력. 언어청각장애연구, 18, 277-287

이은주, 심현섭(2003). 무의미 음절 따라말하기를 통한 단순조음음운장애아동과 정상아동의 음운기억 수행능력 비교연구. 언어청각장애연구, 8 ,

127-145.

이은주, 한진순, 심현섭(2004). 조음복잡성이 비유창성과 조음오류에 미치는 영향. 언어청각장애연구, 9, 139-156.

전희정, 니콜린 앰브로즈(2016). 말더듬이 지속된 아동과 회복된 아동의 비단어 따라말하기 능력: 기초연구. 언어치료연구, 25, 211-222.

하승희, 황진경(2013). 18-47개월 아동의 자발화 분석에 기초한 말소리 측정치에 관한 연구. 언어청각장애연구, 18, 425-434.

황민아(2015). 일반아동의 비단어 따라말하기. 언어청각장애연구, 20(3), 374-385.

황진경, 하승희(2010). 2 세-5세 일반아동의 무의미단어 따라말하기. 언어청각장애연구, 15, 561-571.

황진경, 하승희(2012). 2세 후반-4세 아동의 조음 변이성 연구. 언어청각장애연구, 17, 403-413. 